\title{
Occipitocervical Fixation Using Occipital Bone Hooks and Cervical Lateral Mass Screws: Analysis of 16 Cases
}

\section{Oksipital Kemik Kancaları ve Servikal Yan Kitle Vidalaru Kullanularak Yapulan Oksipitoservikal Fiksasyon: 16 Olgunun Analizi}

Atilla AKBAY, Ilkay ISIKAY, Merdan ORUNOGLU

Hacettepe University, School of Medicine, Department of Neurosurgery, Ankara, Turkey

Corresponding Author: Atilla AKBAY / E-mail: atik@hacettepe.edu.tr

\begin{abstract}
AIM: We present a series of 16 patients who underwent occipitocervical fixation with occipital bone hooks used as a substitute for occipital screws for the treatment of occipitocervical instability.

MATERIAL and METHODS: In this technique; instrumentation was started following the decompression with insertion of screws into lateral masses. At the occipital level, two symmetrical burr holes were drilled and two occipital bone hooks were inserted into each burr hole with an inverted position with respect to each other. Afterwards, rod-plates were placed and locked on the hooks and screw heads. Bone grafting was also performed to achieve a solid fusion.

RESULTS: There were no neurological or vascular complications associated with this technique. No infection-related complications or hematomas were observed. Cerebro-spinal fluid leaks (CSF) occurred when the burr holes were drilled in 4 patients; however, these ceased when the occipital bone hooks were inserted. There were no cases of postoperative CSF fistula or pseudo-meningocele formation. No instrumentation problem was noted in any of the cases during the follow-up period.
\end{abstract}

CONCLUSION: Relatively long term (average 30.44 months) evaluation of the technique in terms of stability is satisfactory with no neurological, vascular or other major complications. However, further biomechanical studies are needed.

KEYWORDS: Occipitocervical instability, Occipitocervical fixation, Occipital bone hook, Figid fixation, Occipital screw

ÖZ

AMAÇ: Bu çalışmada, oksipital vidalar yerine oksipital kemik kancaları kullanılarak yapılan 16 oksipitoservikal fiksasyon olgusu analiz edilmiştir. YÖNTEM ve GEREÇLER: Nöral dekompresyon işlemini takiben servikal vertebraların yan kitlelerine vidalar yerleştirildi. Oksipital skuama üzerine 2 adet simetrik burr-hole açllarak fiksasyon seti ile birlikte gelen 2 adet oksipital kanca burr-hole içerisine birbirlerine ters yönlerde yerleştirildi. Daha sonra rodlar yerleştirilerek fikasayon tamamlandı. Allograft kulanılarak füzyon yapıldı.

BULGULAR: Hastaların hiçbirisinde nöral veya vasküler komplikasyon olmadı, enfeksiyon ve hematom görülmedi. 4 hastada burr-hole açılırken BOS sızıntısı oldu, ancak bu sızıntı kancalar yerleştirildikten sonra kesildi. Hiçbir hastada postoperatif dönemde psödomeningosel veya BOS kaçağı olmadı. Hastaların izlemi süresince herhangi bir enstrüman problem olmadı.

SONUÇ: Ortalama 30,44 aylık izlem süresince hiçbir vasküler ve nörolojik komplikasyon olmadığı gibi stabilite problemi de olmadı. Daha güvenli bir stabilizasyon yöntemi olarak kullanılan oksipital kemik kancaları için yine de ileri biyomekanik çalışmalar gereklidir.

ANAHTAR SÖZCÜKLER: Oksipitoservikal instabilite, Oksipitoservikal fiksasyon, Oksipital kemik kancası, Rijit fiksasyon, Oksipital vida

\section{INTRODUCTION}

The occipito-atlanto-axial junction is responsible for nearly $50 \%$ of the head movements and this junction is stabilized only by ligamentous structures. Therefore, the occipitocervical junction is prone to instability. Trauma, infection, tumor, some congenital disorders, and inflammatory disorders are well-known risk factors for occipitocervical instability. Some surgical procedures in this region have also been described as a risk factor. As in all other conditions that lead to spinal instability, occipitocervical instability finally leads to neural compression $(12,22)$. Hence, occipitocervical fixation and fusion are indicated to treat the instability.

Occipitocervical fusion was first reported by Foerester in 1927 (12). Early techniques included only bone grafting without any internal fixation that required prolonged external fixation and/or bed rest. Since failure rates for fusion were high, addition of supplementary techniques such as wire-securing procedures, countered rods, plate-screw and finally rod-screw fixation constructs have been developed to avoid failure of fusion $(9,17)$. With the aid of these supplementary techniques, 
fusion rates have increased to over $95 \%(12,23)$. On the other hand, occipitocervical fixation with instrumentation has some problems. Plate or rod systems in particular can cause arterial injury, venous-sinus injury, dural penetration, and cerebellar injury during the surgery. The occipital fixation of the instrument also determines the stability. The thickness of the occipital bone is crucial to preclude screw penetration as well as occipital screw pullout.

To avoid vascular and neural injuries and screw pull out, we have used inverted occipital bone hooks for fixation of the occipital side of the instrumentation since 2006. This technique was first introduced by Faure et al. in 1998 (7). While they used one or two cervical hooks inserted through a burr hole in the occipital bone, we have used the occipital bone hooks produced for this purpose. In this article, we present our clinical experience regarding usefulness of occipital bone hooks in occipitocervical instability and discuss our results in the context of the existing literature.

\section{MATERIAL and METHODS}

\section{Patient Population}

This study comprises 16 patients with occipitocervical disorders treated at our department between January 2009 and March 2014. Patients suffered from occipitocervical pathologies such as atlantoaxial dislocation (with or without rheumatoid arthritis), primary or metastatic tumors, congenital disorders and trauma. All the patients underwent placement of rigid posterior occipitocervical instrumentation and fusion. The Vertex Max occipitocervical system (Medtronic Sofamor Danek USA, INC. Memphis, Tennessee 38132 USA) and its occipital bone hooks were used in all of the patients for occipitocervical instrumentation. The only reason for our choice of this system is its occipital bone hooks.

\section{Preparation of the Patient}

Cervical MRI series and 1-mm-thin CT slices were preoperatively obtained for all patients. Multiplanar reconstructions (MPR) on CT slices were performed to demonstrate the osseous anatomy of the occipital bone and vertebrae in detail. MRI was obtained to show soft-tissue lesions and vertebral artery abnormalities. Following informed consent, the patients underwent occipitocervical fixation. Before the surgery, the patients were emphatically informed that they would not be able to perform some head and neck movements over their lifetime after the surgery.

\section{Surgical Procedure}

Surgical procedure was performed after fiberoptic endotracheal intubation under general anesthesia. The patient was placed in the prone position over soft gel cushions and the head was fixed using a three-pin head holder. The head was fixed in the neutral position and was neither too flexed nor too extended. The shoulders were stretched caudally by wide dressing tape to facilitate surgical dissection. Correct occipitocervical position and alignment was ensured with the aid of C-arm fluoroscopy.
A midline incision was made along the spinous processes of the vertebra from the protuberencia occipitalis externa to the $C 7$ level. The paraspinal and suboccipital muscles were stripped through subperiosteal dissection to expose the laminae, the lateral masses of the cervical vertebrae and the occipitocervical junction. The cervical spine and occipital squama were exposed and any necessary decompression procedures were performed. Following the decompression, the surgical field was prepared for instrumentation. Instrumentation was started with insertion of screws into the posterior lateral masses. The screws, sized $3.5 \times 14 \mathrm{~mm}$, were placed bilaterally according to the Magerl technique $(5,14)$. At the occipital level, the position of burr holes for placing the occipital bone hooks has been described by Faure A. et al in 1998. According to these authors, the position of the burr holes should be located $2 \mathrm{~cm}$ from the midline and $3 \mathrm{~cm}$ caudal from the upper nuchal line $(7,8)$. The average bone thickness at this area was measured as $3.7 \pm 1.3 \mathrm{~mm}$ in females and $4.7 \pm 1.6 \mathrm{~mm}$ in males (6). Two symmetrical occipital burr holes were drilled using a high-speed drill and the dura mater was separated from the bone. The diameter of the burr holes was large enough to fit the occipital bone hooks. Two occipital bone hooks that come with the standard Vertex Max posterior occipitocervical instrumentation set were inserted into each burr hole in the craniocaudal direction and in an inverted position with respect to each other. After all lateral mass screws and occipital hooks were placed; the malleable template rods were positioned and shaped bilaterally over the screw heads from the occipital hooks to the most caudal screw. Permanent cervical rod-plates $(5 \mathrm{~mm}$ diameter) were bent to the shape of the template rod. The bent permanent rod-plates were cut to an appropriate length. The occipital part of the rod-plate was fixed on the inverted hooks first and then the cervical part of the rod-plate was placed on the screw heads and locked. The two sides were instrumented one after the other. The transverse linking device was used to strengthen the instrumentation. Although the construct was quite stable, bone grafting was also performed to achieve a solid fusion.

\section{Follow-Up Protocol}

Each patient was mobilized on the following day and discharged on the $7^{\text {th }}$ day after surgery if there was no complication. A Philadelphia collar was applied for 10 days to reduce neck pain. Discharged patients were followed up on the $10^{\text {th }}$ and $45^{\text {th }}$ postoperative days and then at 6-month intervals. The follow-up examination on the $10^{\text {th }}$ day was intended to check the incision and to remove the stitches, whereas the $45^{\text {th }}$ day examination was to check early stage neurological status and for radiological control studies. Physical and neurological examinations were conducted at 6-month intervals. Radiological studies (AP and lateral radiograms) were performed on a yearly basis. MR and/or CT were used only for the patients who suffered from tumor or complained of neck pain. 


\section{RESULTS}

The patients were composed of 9 females (56.25\%) and 7 males (43.75\%), between the ages of 22 and 78 years (mean: 42.69 years). Ten patients had symptomatic basilar invagination with Chiari Type I malformation (62.5\%); 2 patients had a spinal tumor (12.5\%); 2 patients had suffered trauma (12.5\%); 1 patient had rheumatoid arthritis with atlantoaxial dislocation (6.25\%) and 1 patient had Down's syndrome with atlantoaxial dislocation (6.25\%). The mean number of instrumented segments was 4.19 (range: 4-5) and the average follow-up time was 30.44 months (range: 6-60 months). To date, 1 patient (6.25\%) died during the terminal phase of her primary disease (renal cell carcinoma). Preoperatively all patients had severe neck pain. Complete resolution of neck pain occurred in 14 patients $(87.5 \%)$, and partial relief occurred in 2 patients (12.5\%).

We could not perform a short-segment posterior atlantoaxial fixation in any of our 16 patients because some developmental anomalies or previous surgical procedures had destroyed the bone.

There were no neurological or vascular complications associated with this technique. No infection-related complications or hematomas were observed. Cerebro-spinal fluid leaks (CSF) occurred when the burr holes were drilled in 4 patients; however, these ceased when the occipital bone hooks were inserted. There were no cases of postoperative CSF fistula or pseudo-meningocele formation. No instrumentation problem was noted in any of the cases during the follow-up period.

Demographic and outcome data of the treated patients are given in Table I.

\section{Illustrative Case}

A 28-year-old man was admitted to our institution in July 2009 with severe quadriparesis, difficulty in swallowing and neck pain complaints. His medical history revealed that he had undergone a suboccipital craniectomy operation for Chiari Type I malformation in 2007. He had been readmitted to the same center with weakness of arms, gait disturbances, difficulty in swallowing and neck pain in March 2009. A tracheostomy had been performed following aspiration pneumonia. He had then been discharged with a tracheostomy and nasogastric tube for feeding in May 2009.

His neurological examination revealed findings of brain stem compression (diminished "gag" reflexes, severe quadriparesis, spasticity, hyperreflexia, pathologic reflexes) and severe neck pain. His MR studies revealed a basilar invagination and brain stem compression (Figure 1). Ventral brain stem compression associated with Chiari Type I malformation is already a well-known pathology (10). Endoscopic transnasal odontoidectomy followed by widening previous foramen magnum decompression (Figure 2A, B), posterior occipitocervical fixation and fusion with allografts were performed (Figure $3 ; 4 \mathrm{~A}, \mathrm{~B}$ ). He was discharged on the $1^{\text {st }}$ postoperative month. His tracheostomy was closed before discharge. He was able to eat, use his hands for personal care and walk with assistance at discharge. His neurological symptoms and signs gradually improved and the construct was stable during the 24-month follow-up examinations.

\section{DISCUSSION}

Head and neck movements are anatomically very complex. The occipitocervical junction, which comprises the occiput, atlas, and axis, represents a unique and complex interface between the cranium and the rostral cervical spine. It is one of the most mobile sections of the spine. The occipitocervical junction is responsible for nearly $50-60 \%$ of the range of motion of flexion and rotation movements. The atlantoaxial joint is also responsible for flexion, extension and lateral bending. Therefore, the occipitocervical junction, which has a wide range of motion, is also prone to instability $(11,19$, 20, 22). Occipitocervical instability can be caused by many diseases, such as tumor, trauma, congenital anomalies, inflammatory diseases, degenerative diseases and iatrogenic causes $(1,3,4,15)$.

Foerester, the pioneer of occipitocervical fusion, attempted to fuse occipitocervical instability, which was considered to be inoperable till that time, by using a fibular graft $(12$, 22). Various occipitocervical fixation and fusion techniques have been introduced since then. Each technique has its advantages and disadvantages. Most of these techniques provide stability, although screw-rod and screw-plate techniques are more stable than others (23). The thickness of the occipital bone determines the success of screw-rod and screw-plate fixation techniques $(18,21)$; because pullout from the occiput by screws and plates is one of the most

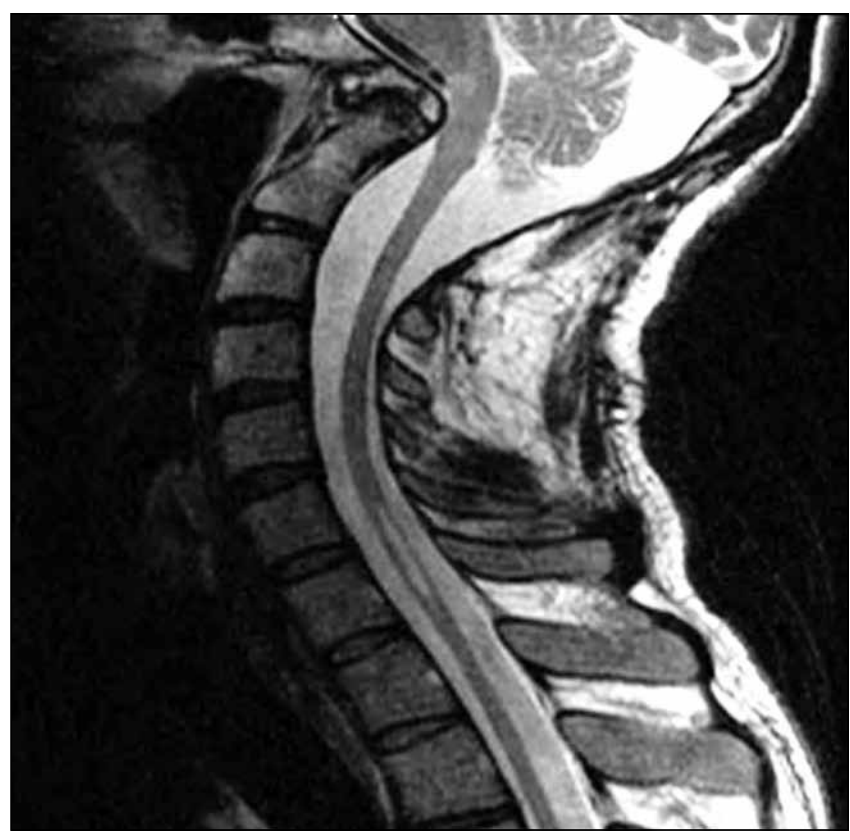

Figure 1: Preoperative T2 weighted sagittal magnetic resonance image showing basilar invagination and ventral brain stem compression. 
Table I: Data in 16 Patients Who Underwent Occipitocervical Stabilization Using Occipital Bone Hooks

\begin{tabular}{|c|c|c|c|c|c|}
\hline $\begin{array}{l}\text { Case } \\
\text { No }\end{array}$ & $\begin{array}{l}\text { Age } \\
\text { (years) } \\
\text { Sex }\end{array}$ & Pathology, History & Surgery & $\begin{array}{c}\text { F/U } \\
\text { (Months) }\end{array}$ & Outcome \\
\hline 1 & $53 / \mathrm{M}$ & $\begin{array}{l}\text { Chiari malformation, basilar invagination, } \\
\text { qauriparesis, unable to walk }\end{array}$ & $\mathrm{SOC}+\mathrm{POCl}$ & 10 & $\begin{array}{l}\text { Walking independently and } \\
\text { resumed activity }\end{array}$ \\
\hline 2 & $24 / F$ & $\begin{array}{l}\text { Chiari malformation, basilar invagination, } \\
\text { assimilation of atlas, brain stem } \\
\text { compression, gait disturbance, swallowing } \\
\text { difficulty, severe neck pain }\end{array}$ & $\mathrm{SOC}+\mathrm{POCl}$ & 12 & $\begin{array}{l}\text { Gait improved, walking } \\
\text { independently and resumed } \\
\text { activity, pain decreased }\end{array}$ \\
\hline 3 & $59 / F$ & $\begin{array}{l}\text { Chiari malformation, basilar invagination, } \\
\text { SOC, difficulty in walking, neck pain }\end{array}$ & $\mathrm{SOC}+\mathrm{POCl}$ & 27 & Gait improved, pain decreased \\
\hline 4 & $64 / M$ & C2 metastatic tumor (renal cell carcinoma) & $\mathrm{TE}+\mathrm{POCl}$ & 36 & Died of primary disease \\
\hline 5 & $42 / \mathrm{F}$ & C2 chordoma & $\mathrm{TE}+\mathrm{POCl}$ & 56 & $\begin{array}{l}\text { Pain decreased and performed } \\
\text { cyber-knife }\end{array}$ \\
\hline 6 & 28/M & $\begin{array}{l}\text { Chiari malformation, basilar invagination, } \\
\text { severe quadriparetic, bedridden, difficulty } \\
\text { in swallowing, trachestomy (+), neck pain }\end{array}$ & $\begin{array}{l}\mathrm{EOE}+\mathrm{SOC}+ \\
\mathrm{POCl}\end{array}$ & 24 & $\begin{array}{l}\text { He can eat with fork and } \\
\text { spoon, swallowing improved, } \\
\text { tracheostomy closed, rehab. for } \\
\text { lower extremities }\end{array}$ \\
\hline 7 & $25 / \mathrm{F}$ & $\begin{array}{l}\text { Chiari malformation, basilar invagination, } \\
\text { walking with assistance, failed fixation and } \\
\text { fusion, neck pain }\end{array}$ & $\mathrm{SOC}+\mathrm{POCl}$ & 36 & $\begin{array}{l}\text { Gait improved, walking } \\
\text { independently and resumed activity }\end{array}$ \\
\hline 8 & 39/M & $\begin{array}{l}\text { Chiari malformation, basilar invagination, } \\
\text { brain stem compression, hoarseness, } \\
\text { difficulty in walking, difficulty in } \\
\text { swallowing, neck pain }\end{array}$ & $\begin{array}{l}\mathrm{EOE}+\mathrm{SOC}+ \\
\mathrm{POCl}\end{array}$ & 42 & $\begin{array}{l}\text { Gait improved, walking } \\
\text { independently, hoarseness } \\
\text { improved, resumed activity }\end{array}$ \\
\hline 9 & $41 / M$ & $\begin{array}{l}\text { Chiari malformation, basilar invagination, } \\
\text { SOC, difficulty in walking, severe neck pain }\end{array}$ & $\mathrm{POCl}$ & 60 & Gait improved, pain decreased \\
\hline 10 & $51 / F$ & $\begin{array}{l}\text { Atlas } \mathrm{fx} \text {, hangman } \mathrm{fx} \text {, halo vest, failed } \\
\text { fusion, neck pain }\end{array}$ & $\mathrm{POCl}$ & 24 & $\begin{array}{l}\text { Pain decreased, walking } \\
\text { independently }\end{array}$ \\
\hline 11 & $60 / \mathrm{M}$ & $\begin{array}{l}\text { RA, } A A D \text {, neck pain, difficulty in walking } \\
\text { failed posterior fixation and fusion, }\end{array}$ & $\mathrm{POCl}$ & 36 & Pain decreased, walking with stick \\
\hline 12 & $47 / F$ & $\begin{array}{l}\text { Chiari malformation, basilar invagination, } \\
\text { brain stem compression, quadriparetic, } \\
\text { hoarseness, neck pain }\end{array}$ & $\begin{array}{l}\mathrm{EOE}+\mathrm{SOC}+ \\
\mathrm{POCl}\end{array}$ & 36 & $\begin{array}{l}\text { Gait improved, walking } \\
\text { independently and returned to } \\
\text { work }\end{array}$ \\
\hline 13 & $78 / \mathrm{M}$ & Jefferson $\mathrm{fx}, \mathrm{C} 2 \mathrm{fx}$, quadriparetic & $\mathrm{POCl}$ & 32 & Gait improved, walking with stick \\
\hline 14 & $27 / F$ & $\begin{array}{l}\text { Chiari malformation, basilar invagination, } \\
\text { brain stem compression, quadriparetic, } \\
\text { difficulty in swallowing, neck pain }\end{array}$ & $\begin{array}{l}\mathrm{EOE}+\mathrm{SOC}+ \\
\mathrm{POCl}\end{array}$ & 26 & $\begin{array}{l}\text { Pain decreased, gait improved } \\
\text { swallowing improved, undergoing } \\
\text { rehab. }\end{array}$ \\
\hline 15 & $23 / M$ & $\begin{array}{l}\text { Down's Syndrome, AAD, quadriparetic, } \\
\text { bedridden, failed fixation and fusion, } \\
\text { severe neck pain }\end{array}$ & $\mathrm{POCl}$ & 24 & $\begin{array}{l}\text { Undergoing rehab., walking } \\
\text { independently, he can eat with fork } \\
\text { and spoon, decreased pain }\end{array}$ \\
\hline 16 & $22 / \mathrm{M}$ & $\begin{array}{l}\text { Chiari malformation, basilar invagination, } \\
\text { difficulty in walking, failed fixation and } \\
\text { fusion severe neck pain }\end{array}$ & $\mathrm{SOC}+\mathrm{POCl}$ & 6 & $\begin{array}{l}\text { Gait improved, walking } \\
\text { independently, pain decreased }\end{array}$ \\
\hline
\end{tabular}

F/U: Follow up, M: Male, F: Female, RA: Rheumatoid arthritis, fx: Fracture, AAD: Atlantoaxial dislocation, SOC: Suboccipital craniectomy , POCI: Posterior occipitocervical fixation, EOE: Endoscopic transnasal-transsfenoidal odontidectomy, TOE: transoral odontoidectomy. 



Figure 2: Postoperative CT A) sagittal and B) coronal reconstructions after widening the suboccipital decompression and endoscopic transnasal odontoidectomy.

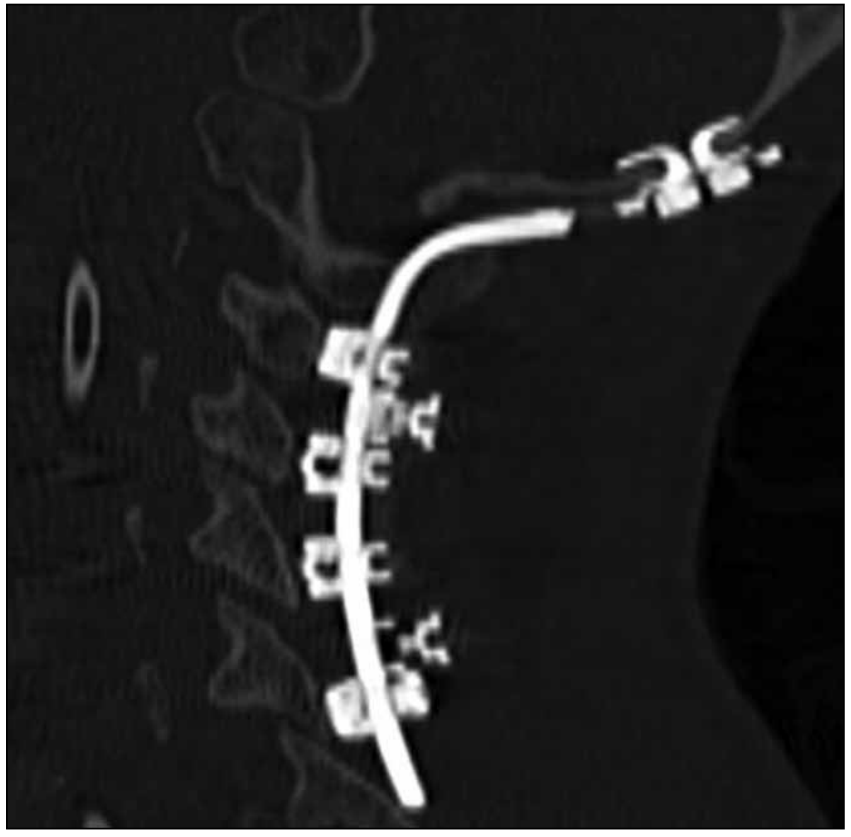

Figure 3: Post-operative CT sagittal reconstruction of the same patient. The image passes through a paramedian sagittal plane showing the construct in situ. Large bone contact surface of occipital hooks is seen.

important problems encountered in occipitocervical fixation $(16,18,21,24)$. The thickness of the posterior inferior occipital bone was measured relative to a $10 \times 5 \mathrm{~cm}$ grid by Nabil et al in 1996. They showed that the maximum thickness at the level of the external occipital protuberance ranged from 11.5 $\mathrm{mm}$ to $15.1 \mathrm{~mm}$ in males and 9 to $12 \mathrm{~mm}$ in females. The authors also showed that the dural sinuses were situated beneath the thickest regions of the occiput (6). If the occipital screws are not positioned close to the superior nuchal line and midline (thickest regions), poor purchase may result. On the other hand, dural venous sinus injury is not uncommonly encountered when the occipital screws placed through the thickest regions of the occipital bone to achieve high pullout resistance $(6,24)$. Hwang et al reported that the rate of intraoperative complications was $15 \%$ in occipital screw placement (14). Fixation involving unicortical occipital screws is less dangerous, although it provides poorer pull-out resistance than bicortical screws (7).

In the inverted occipital hook technique introduced by Faure et al, the bone hooks are placed on the squamous part of the occipital bone and far from the dural venous sinuses (7). Bone thickness at this region is adequate to provide solid anchorage for the occipital hooks. This technique also offers some important advantages over occipital screws. The hooks are not placed in blind fashion (in contrast to screws), and the surgeon closely observes the entire procedure therefore reducing the risk of dural tear and cerebellar injury. However, to prevent complications, meticulous radiologic studies are essential to determine preoperatively the thickness of the occipital squama and the position of the dural venous sinuses $(2,13)$.

In our series consisting of 16 adult patients, we utilized the occipital bone hooks provided with the Vertex Max Occipitocervical Fixation System (Medtronic Sofamor Danek USA, INC. Memphis, Tennessee 38132 USA). We believe that occipital bone hooks are used by some surgeons. However we have not been able to find a report where occipital bone hooks were used in the English literature. In our case series, we observed no vascular or neural injury, no loss of stability and no instrumentation problem with an average follow-up time of 30.44 months (range: 6-60 months). 

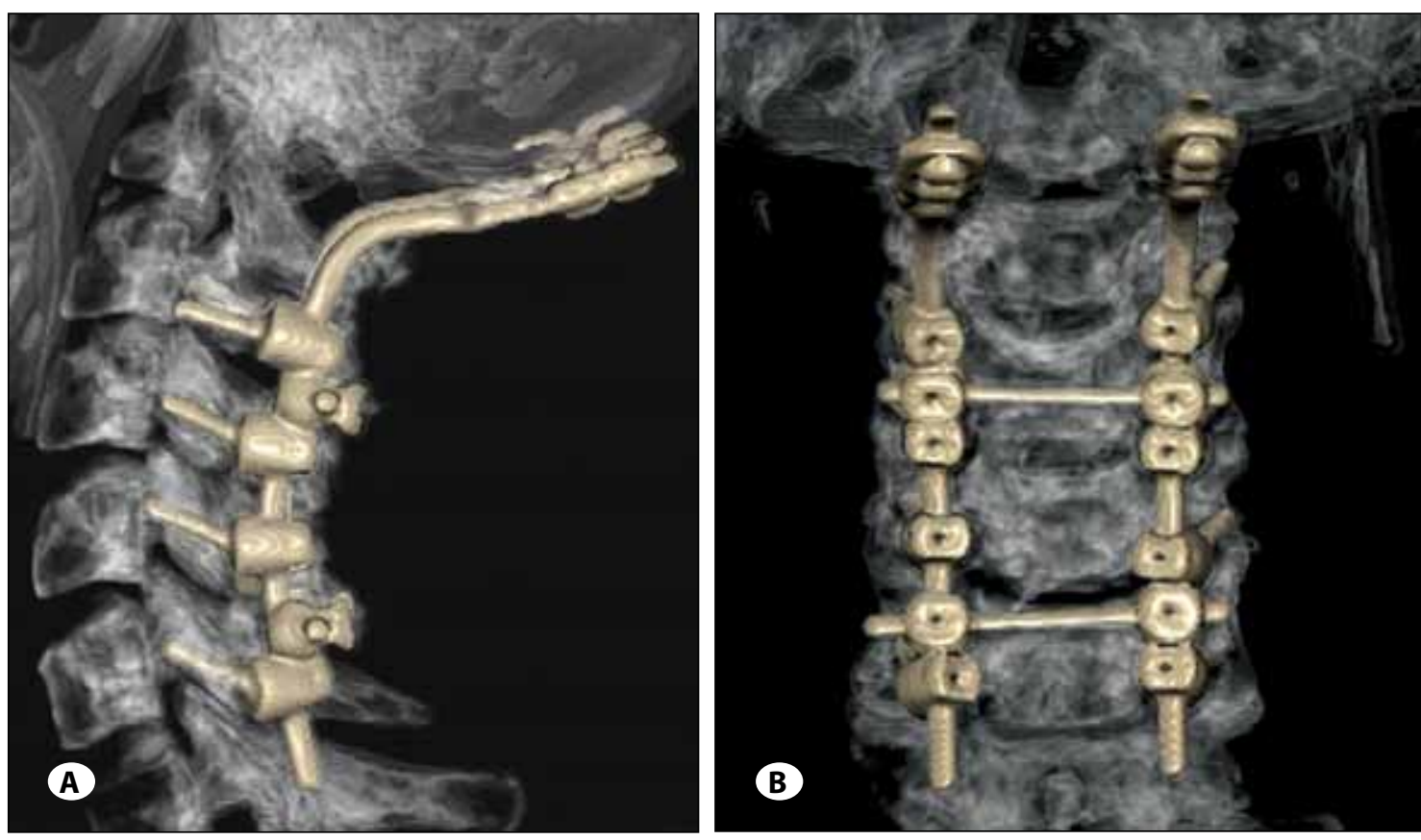

Figure 4A,B:

Postoperative

3D-CT

reconstructions

showing

occipitocervical

fixation using

occipital bone

hooks.

\section{CONCLUSION}

We have used occipital bone hooks as a substitute for occipital screws for the treatment of occipitocervical instability in 16 patients. To the best of our knowledge, this study is one of the largest published series using occipital hooks on occipitocervical fixation. Relatively long term (average 30.44 months) evaluation of the technique in terms of stability was satisfactory with no neurological, vascular or other major complications. The major benefits of this technique are:

1) Occipital bone hooks are easier to manipulate and can minimize the risk of injury to the neural tissue and dural venous sinuses.

2) Occipital bone hooks reduce the metal load in the patient, resulting in less metal artefacts in MR and CT.

According to our experience, occipital hooks can be a useful alternative to occipital screws. However, further biomechanical studies are needed.

\section{REFERENCES}

1. Bertalanffy H, Seeger W: The dorsolateral, suboccipital, transcondylar approach to the lower clivus and anterior portion of the craniocervical junction. Neurosurgery 29(6):815-821, 1991

2. Bhatia R, Desouza RM, Bull J, Casey AT: Rigid occipitocervical fixation: Indications, outcomes, and complications in the modern era. J Neurosurg Spine 18(4):333-339, 2013

3. Bucholz RW, Burkhead WZ: The pathological anatomy of fatal atlanto occipital dislocations. J Bone Joint Surg Am 61(2): 248-250, 1979
4. Crockard HA, Essigman WK, Stevens JM, Pozo JL, Ransford AO, Kendall BE: Surgical treatment of cervical cord compression in rheumatoid arthritis. Ann Rheum Dis 44(12):809-816, 1985

5. Ebraheim N: Posterior lateral mass screw fixation:Anatomic and radiographic considerations. University of Pennsylvania Orthopaedic Journal 12:66-72, 1999

6. Ebraheim NA, Lu J, Biyani A, Brown JA, Yeasting RA: An anatomic study of the thickness of the occipital bone. Implications for occipitocervical instrumentation. Spine (Phila Pa 1976) 21(15):1725-1729, 1996

7. Faure A, Monteiro R, Hamel O, Raoul S, Szapiro J, Alcheikh M, Bord E, Robert R: Inverted-hook occipital clamp system in occipitocervical fixation. Technical note. J Neurosurg (1 Suppl) 97:135-141, 2002

8. Faure A, Bord E, Monteiro da Silva R, Diaz Saldana A, Robert R: Occipitocervical fixation with a single occipital clamp using inverted hooks. Eur Spine J 7(1):80-83, 1998

9. Fielding JW, Hawkins RJ, Ratzan SA: Spine fusion for atlantoaxial instability. J Bone Joint Surg Am 58(3):400-407, 1976

10. Grabb PA, Mapstone TB, Oakes WJ: Ventral brain stem compression in pediatric and young adult patients with Chiari I malformations. Neurosurgery 44(3):520-527, 1999

11. Haher TR, Yeung AW, Caruso SA, Merola AA, Shin T, Zipnick RI, Gorup JM, Bono C: Occipital screw pullout strength. A biomechanical investigation of occipital morphology. Spine (Phila Pa 1976) 24(1):5-9, 1999

12. Helgeson MD, Lehman RA Jr, Sasso RC, Dmitriev AE, Mack AW, Riew KD: Biomechanical analysis of occipitocervical stability afforded by three fixation techniques. Spine J 11(3):245-250, 2011 
13. Hwang SW, Gressot LV, Chern JJ, Relyea K, Jea A: Complications of occipitalscrew placement for occipitocervical fusion in children. J Neurosurg Pediatr 9(6):586-593, 2012

14. Jeanneret B, Magerl F, Ward EH, Ward JC: Posterior stabilization of the cervical spine with hook plates. Spine (Phila Pa 1976) 16(3 Suppl):S56-63, 1991

15. Menezes AH, VanGilder JC: Transoral-transpharyngeal approach to the anterior craniocervical junction. Ten-year experience with 72 patients. J Neurosurg 69(6):895-903, 1988

16. Menezes AH: Occipitocervical fixation. World Neurosurg 73(6):635-637, 2010

17. Murphy MJ, Daniaux H, Southwick WO: Posterior cervical fusion with rigid internal fixation. Orthop Clin North Am 17(1):55-65, 1986

18. Nockels RP, Shaffrey $\mathrm{Cl}$, Kanter AS, Azeem S, York JE: Occipitocervical fusion with rigid internal fixation: Long-term follow-up data in 69 patients. J Neurosurg Spine 7(2):117-123, 2007

19. Pang D, Li V: Atlantoaxial rotatory fixation: Part 2--new diagnostic mparadigm and a new classification based on motion analysis using computed tomographic imaging. Neurosurgery 57(5):941-953, 2005
20. Pang D, Li V: Atlantoaxial rotatory fixation: Part 3-a prospective study of the clinical manifestation, diagnosis, management, and outcome of children with alantoaxial rotatory fixation. Neurosurgery 57(5):954-972, 2005

21. Paquis P, Breuil V, Lonjon M, Euller-Ziegler L, Grellier P: Occipitocervical fixation using hooks and screws for upper cervical instability. Neurosurgery 44(2):324-330, 1999

22. Vender JR, Rekito AJ, Harrison SJ, McDonnell DE: The evolution of posterior cervical and occipitocervical fusion and instrumentation. Neurosurg Focus 16(1):E9, 2004

23. Winegar CD, Lawrence JP, Friel BC, Fernandez C, Hong J, Maltenfort M, Anderson PA, Vaccaro AR: A systematic review of occipital cervical fusion: Techniques and outcomes. J Neurosurg Spine 13(1):5-16, 2010

24. Zipnick RI, Merola AA, Gorup J, Kunkle K, Shin T, Caruso SA, Haher TR: Occipital morphology. An anatomic guide to internal fixation. Spine (Phila Pa1976) 21(15):1719-1724, 1996 